\title{
Ovarian Structures and Circulating Steroids in Heifers and Lactating Cows in Summer and Lactating and Dry Cows in Winter
}

\author{
R. Sartori, ${ }^{\star}$ G. J. M. Rosa, $†$ and M. C. Wiltbank* \\ *Dairy Science Department, \\ University of Wisconsin, \\ Madison 53706; and \\ †Department of Animal Science, \\ Michigan State University, \\ East Lansing 48824
}

\section{ABSTRACT}

Two experiments compared follicular and luteal development and circulating steroid concentrations from induced luteolysis to ovulation in lactating Holstein cows ( $\mathrm{n}=27 ; 40.0 \pm 1.5 \mathrm{~kg}$ milk/day) vs. nulliparous heifers ( $\mathrm{n}=28 ; 11$ to 17 mo-old) during summer (Experiment 1$)$, and in lactating ( $\mathrm{n}=27 ; 45.9 \pm 1.4 \mathrm{~kg} \mathrm{milk} / \mathrm{d})$ vs. dry cows $(\mathrm{n}=26)$ during winter (experiment 2$)$. All females received $\mathrm{PGF}_{2 \alpha} 6 \mathrm{~d}$ after ovulation and were monitored until next ovulation by daily ultrasound and assay of serum progesterone $\left(\mathrm{P}_{4}\right)$ and estradiol $\left(\mathrm{E}_{2}\right)$. Every female was used two or three times. In Experiment 1, lactating cows had high incidence of multiple ovulation (63.5\%) compared with heifers (1.3\%). Among single ovulators, there was no difference in maximal size of ovulatory follicles between lactating cows and heifers (15.8 vs. $16.5 \mathrm{~mm}$, respectively). However, lactating cows had lower peak serum $\mathrm{E}_{2}$ (8.6 vs. $12.1 \mathrm{pg} /$ $\mathrm{ml}$ ), took longer to ovulate after luteolysis ( $4.6 \mathrm{vs} .3 .8 \mathrm{~d}$ ), developed more luteal tissue volume (7293.6 vs. 5515.2 $\mathrm{mm}^{3}$ ), and had lower serum $\mathrm{P}_{4}$ on d 6 after ovulation $(2.0 \mathrm{vs} .3 .0 \mathrm{ng} / \mathrm{ml}$ ) than heifers (data included multiple ovulators). In experiment 2 , multiple ovulations were similar between lactating and dry cows (17.9 vs. $17.2 \%$, respectively). Peak serum $\mathrm{E}_{2}$ was also similar between lactating and dry cows ( $7.6 \mathrm{vs} .8 .5 \mathrm{pg} / \mathrm{ml}$ ) although lactating cows had larger ovulatory follicles (18.6 vs. 16.2 $\pm 0.4 \mathrm{~mm})$. Lactating cows took longer to ovulate (4.8 vs. $4.2 \mathrm{~d}$ ), developed more luteal tissue (7599 vs. 5139 $\pm 468 \mathrm{~mm}^{3}$ ), but had similar serum $\mathrm{P}_{4}(2.2$ vs. $1.9 \mathrm{ng} /$ $\mathrm{ml}$ ) compared with dry cows. Therefore, lactating cows had similar or lower circulating steroid concentrations than dry cows or heifers, respectively, despite having larger ovarian structures.

Received November 7, 2001.

Accepted May 3, 2002.

Corresponding author: M. C. Wiltbank; e-mail: Wiltbank@calshp. cals.wisc.edu.
(Key words: ovary, estradiol, progesterone, dairy cattle)

Abbreviation key: $\mathbf{C L}=$ corpus luteum or corpora lutea, $\mathbf{C R}=$ conception rate, $\mathbf{E}_{\mathbf{2}}=$ estradiol, $\mathbf{P}_{4}=$ progesterone.

\section{INTRODUCTION}

The increase in milk yield for lactating dairy cows is associated with a decrease in fertility (Faust et al., 1988; Nebel and McGilliard, 1993; Butler, 1998; Washburn et al., 2002), and is also associated with an increase in DMI (Harrison et al., 1990). In sheep (Parr et al., 1993a, 1993b), increased DMI increases the rate of blood flow to the liver and consequently increases the clearance rate for progesterone $\left(\mathbf{P}_{4}\right)$ because about $90 \%$ of $\mathrm{P}_{4}$ that flows through the liver is metabolized. In pregnant lactating dairy cows, Vasconcelos et al. (1998) also showed that increased feed consumption decreases circulating $\mathrm{P}_{4}$ concentrations.

Many studies in cows (Sirois and Fortune, 1990; Ahmad et al., 1996; Kinder et al., 1996) have identified that low-circulating progestin concentrations (as produced by many programs for synchronization of estrus) produce aberrant growth of the dominant follicle such that the follicle becomes very large due to prolonged stimulation with LH (persistent follicle). Vasconcelos et al. (1999) detected a direct correlation between milk production and the size of the ovulatory follicle, and an inverse correlation between milk production and the serum $\mathrm{P}_{4}$ concentrations on $\mathrm{d} 16$ of the estrous cycle. They also observed that cows beginning the Ovsynch protocol (GnRH-7d-PGF ${ }_{2 \alpha}-2 \mathrm{~d}-\mathrm{GnRH}-1 \mathrm{~d}-\mathrm{AI}$; Pursley et al., 1995) either early or late in the estrous cycle, when serum $\mathrm{P}_{4}$ concentrations were low, ovulated larger follicles. Thus, it appears that "persistent" follicles may naturally occur in cows with high milk production, and this may result in a larger corpus luteum $(\mathbf{C L})$ in lactating dairy cows because there is a direct positive relationship between the diameter of the ovulatory follicle 
and the diameter of the resulting CL (Vasconcelos et al., 2001). Nevertheless, it seems likely that the potential increase in circulating $\mathrm{P}_{4}$ and estradiol $\left(\mathbf{E}_{2}\right)$ concentrations that would be expected by the increased follicular and luteal sizes could be blunted by the increase in $\mathrm{P}_{4}$ and $\mathrm{E}_{2}$ metabolism in lactating cows.

The present study was designed to compare the size of follicles and CL (by ultrasound) and circulating $\mathrm{P}_{4}$ and $\mathrm{E}_{2}$ concentrations between lactating and nonlactating dairy cattle. We hypothesized that lactating cows would ovulate larger follicles but would have similar peak $\mathrm{E}_{2}$ concentrations. Further, we hypothesized that lactating cows would have larger CL but would have similar circulating $\mathrm{P}_{4}$ concentrations. The discrepancies between circulating steroids and follicular or luteal sizes were hypothesized to occur due to increased steroid metabolism in lactating as compared with nonlactating females. To investigate these hypotheses, two experiments examined follicular and luteal sizes and serum steroid concentrations from the time of induced luteolysis to ovulation in lactating cows and nulliparous heifers during summer (experiment 1) and in lactating cows and dry cows during winter (experiment 2).

\section{MATERIALS AND METHODS}

\section{Experiment 1}

Animals. A detailed description of the cows, feed, treatments of anovulatory cows, and reproductive management program for experiment 1 can be found in Sartori et al. (2002). Lactating Holstein cows $(\mathrm{n}=27)$ and nulliparous Holstein heifers $(\mathrm{n}=28)$ were compared during summer 1999. All cows and heifers had undergone one normal estrous cycle, and data collection began on the follicle leading up to the natural ovulation following this estrous cycle. Previously anovulatory cows were only included in the experiment after completing a normal estrous cycle. All cows and heifers were bred to this natural estrus/ovulation, and embryo collection occurred on d 6 (d $0=$ day before detected ovulation). On $\mathrm{d} 7$ and 8 , all females received i.m. injections of a $\mathrm{PGF}_{2 \alpha}$ analog (Estrumate; Bayer Corporation, Shawnee Mission, KS; $500 \mu \mathrm{g}$ on d 7 and $250 \mu \mathrm{g}$ on d 8 ) and were observed for estrus and ovulation. Ovarian ultrasonography was performed, and blood samples were collected by coccygeal venipuncture on the day of $\mathrm{PGF}_{2 \alpha}$ treatment and daily thereafter until the next ovulation. Serum samples were stored at $-20^{\circ} \mathrm{C}$ until assayed for $\mathrm{P}_{4}$ and $\mathrm{E}_{2}$. Every cow or heifer was monitored from ovulation until subsequent $\mathrm{PGF}_{2 \alpha}$-induced luteolysis either two or three times. Transrectal ultrasound (Aloka 500-V with a 7.5 MHz linear-array transducer; Corometrics Medical Systems Inc., Wallingford, CT) was used to determine size of the CL and ovulatory follicle(s), and to confirm ovulation. Ultrasound measurements of follicles and CL (length [L] and width [W]) were recorded and used to calculate the average diameter and volume (V). Volume was calculated with the formula $V=4 / 3 \times \pi \times R^{3}$ using a radius $(R)$ calculated by the formula $\mathrm{R}=(\mathrm{L} / 2+\mathrm{W} / 2) / 2$. For CL with a fluidfilled cavity, the volume of the cavity was calculated and subtracted from the total volume of the CL.

\section{Experiment 2}

Animals. A detailed description of the cows, feed, treatments of anovulatory cows, and reproductive management program for experiment 2 can be found in Sartori et al. (2002). Lactating Holstein cows $(n=27)$ and nonpregnant nonlactating (dry) Holstein cows ( $\mathrm{n}=$ 26) were compared in experiment 2 during the winter of 1999-2000. Before collection of data, all cows received an i.m. GnRH injection $(100 \mu \mathrm{g})$ followed $7 \mathrm{~d}$ later by i.m. PGF $_{2 \alpha}$ (25 mg; ProstaMate; Phoenix Pharmaceutical Inc., St. Joseph, MO). Cows were observed for estrus twice daily (20 min each time) using an androgenized cow. Cows were also fitted with a pressure-activated heat mount detector (Kamar; Kamar Inc., Steamboat Springs, CO) to aid in detection of estrus. Previously anovulatory cows were included only after a natural ovulation. Ovarian ultrasonography was performed, and blood samples were collected on d 7 (d $0=$ day before detected ovulation). Cows were treated on $d 7$ with $\mathrm{PGF}_{2 \alpha}(25 \mathrm{mg})$, and daily ovarian ultrasonography and blood collection were performed until next ovulation. As in experiment 1, collection of data following $\mathrm{PGF}_{2 \alpha}$-induced luteolysis was performed two or three times in each cow.

\section{Hormonal Assays}

Serum was evaluated for $\mathrm{P}_{4}$ concentration using double extraction of serum with petroleum ether and subsequent ELISA as previously reported (Rasmussen et al., 1996). For analysis of $E_{2}$, samples were extracted twice with diethyl ether, and serum concentrations of $\mathrm{E}_{2}$ were evaluated as previously reported (Kulick et al., 1999). The intraassay CV was $8.9 \%$ for $\mathrm{P}_{4}$ and $3.3 \%$ for $\mathrm{E}_{2}$.

\section{Statistical Analyses}

Data were collected from the time of first treatment with $\mathrm{PGF}_{2 \alpha}$ until the time of last ovulation in both experiments. However, data were not utilized for luteal tissue volume or serum $\mathrm{P}_{4}$ at the time of first $\mathrm{PGF}_{2 \alpha}$ treatment in experiment 2 because of the potential confounding effects from the GnRH treatment $7 \mathrm{~d}$ before $\mathrm{PGF}_{2 \alpha}$. 
Table 1. Follicular and luteal sizes, serum steroid concentrations at the time (d 7; ovulation = d 1) and/or after $\mathrm{PGF}_{2 \alpha}$ injection, growth rate of the ovulatory follicle and days from $\mathrm{PGF}_{2 \alpha}$ injection to ovulation in lactating cows with single $(\mathrm{n}=19)$ and multiple $(\mathrm{n}=33)$ ovulations (experiment 1$){ }^{1}$

\begin{tabular}{|c|c|c|c|}
\hline & $\begin{array}{l}\text { Single-ovulating } \\
\text { cows }\end{array}$ & $\begin{array}{l}\text { Multiple-ovulating } \\
\text { cows }\end{array}$ & $P$-value \\
\hline Ovulatory follicles (no.) & $1.0 \pm 0.0$ & $2.5 \pm 0.1$ & $<0.0001$ \\
\hline $\begin{array}{l}\text { Size of the largest ovulatory follicle } \\
\text { at } \mathrm{PGF}_{2 \alpha}(\mathrm{mm})\end{array}$ & $12.2 \pm 0.4(\mathrm{n}=19)$ & $10.5 \pm 0.3(\mathrm{n}=33)$ & 0.0023 \\
\hline $\begin{array}{l}\text { Maximal size of the largest } \\
\text { ovulatory follicle (mm) }\end{array}$ & $15.8 \pm 0.4(\mathrm{n}=19)$ & $13.7 \pm 0.3(\mathrm{n}=33)$ & 0.0002 \\
\hline $\begin{array}{l}\text { Growth rate of the largest ovulatory } \\
\text { follicle after } \mathrm{PGF}_{2 \alpha}(\mathrm{mm} / \mathrm{d})\end{array}$ & $1.0 \pm 0.1(\mathrm{n}=19)$ & $0.8 \pm 0.1(\mathrm{n}=33)$ & 0.1061 \\
\hline Estradiol peak near estrus (pg/ml) & $9.0 \pm 1.0(\mathrm{n}=15)$ & $8.3 \pm 0.7(\mathrm{n}=28)$ & 0.5836 \\
\hline Days from $\mathrm{PGF}_{2 \alpha}$ to ovulation & $4.5 \pm 0.2(\mathrm{n}=19)$ & $4.7 \pm 0.2(\mathrm{n}=33)$ & 0.4908 \\
\hline Progesterone on d $7(\mathrm{ng} / \mathrm{ml})$ & $1.8 \pm 0.2(\mathrm{n}=29)$ & $2.2 \pm 0.2(\mathrm{n}=38)$ & 0.1500 \\
\hline Luteal tissue volume on $\mathrm{d} 7\left(\mathrm{~mm}^{3}\right)$ & $6178.7 \pm 516.4(\mathrm{n}=29)$ & $8542.3 \pm 453.8(\mathrm{n}=38)$ & 0.0010 \\
\hline
\end{tabular}

${ }^{1}$ Results are expressed as mean \pm SEM.

Data related to luteal tissue volume, serum $\mathrm{P}_{4}$ and $\mathrm{E}_{2}$ concentrations, and number of days from $\mathrm{PGF}_{2 \alpha}$ injection to ovulation were analyzed using a linear mixedeffects model, with the (fixed) effect of group (heifers $[\mathrm{H}]$, cows with single ovulation [CS], and cows with multiple ovulations $[\mathrm{CM}]$, for experiment 1 ; and dry $[\mathrm{D}]$ and lactating $[\mathrm{L}]$ cows for experiment 2), and two residual terms, within and between animals. For Experiment $1, \mathrm{~F}$ tests were used to study two orthogonal contrasts of interest: $\mathrm{H}$ vs. cows (CS and CM), and CS vs. CM; and for experiment $2, \mathrm{~F}$ tests were used to compare D vs. L. For experiments 1 and 2, data for size and growth rate of the largest ovulatory follicle were analyzed using a similar approach, but considering just females with single ovulation. The analyses were performed using the MIXED procedure of SAS (Littell et al., 1996). Ovulation rate was studied using the chisquare test. Pearson correlation coefficient tests were performed to study the relationships between maximal size of the ovulatory follicle, subsequent CL volume on $\mathrm{d} 7$, and serum $\mathrm{P}_{4}$ concentrations on $\mathrm{d} 7$. The procedure CORR of SAS (SAS, 1996) was used to study relationships within groups; the MANOVA statement was considered for correlations using data from all three groups. Regression studies of volume of the ovulatory follicle and serum $\mathrm{P}_{4}$ concentration vs. CL volume for single-ovulating heifers, lactating cows, and dry cows were carried out by using the procedures GLM and REG of SAS (SAS, 1996).

\section{RESULTS}

\section{Experiment 1}

Unexpectedly, during experiment 1, lactating cows had a very high incidence of multiple ovulation (two to five follicles being ovulated simultaneously from the same cow; Wiltbank et al., 2000; Tables 1 and 2). This necessitated the division of lactating cow ovulations into two subgroups with either single $(\mathrm{n}=19)$ or multiple $(n=33)$ ovulations and comparison of several reproductive values between these two subgroups. There was no difference between single- or multiple-ovulating cows for peak serum $\mathrm{E}_{2}$ near estrus even though there were more ovulatory follicles per cow for the multipleovulating cows. The largest ovulatory follicle was greater in diameter at the time of $\mathrm{PGF}_{2 \alpha}$ and at maximal size in single- compared with multiple-ovulating cows. Similarly, the average size (using all ovulating follicles) of the ovulatory follicle(s) at the time of $\mathrm{PGF}_{2 \alpha}(12.2 \pm$ 0.4 vs. $9.4 \pm 0.3 \mathrm{~mm})$ as well as close to ovulation (15.8 \pm 0.4 vs. $12.7 \pm 0.3 \mathrm{~mm})$ was larger $(P<0.0001)$ for single- than for multiple-ovulating cows. The multipleovulating cows had greater $(P=0.03)$ follicular volume $\left(2674.4 \pm 126.8\right.$ vs. $\left.2202.8 \pm 168.5 \mathrm{~mm}^{3}\right)$ and luteal volume (Table 1) than single-ovulating cows. There was no difference between single- and multiple-ovulating cows for the growth rate of the largest ovulatory follicle after luteolysis, days from $\mathrm{PGF}_{2 \alpha}$ injection to ovulation, or for serum $\mathrm{P}_{4}$ concentrations on d 7 (Table 1).

Multiple ovulation rate was much greater in lactating cows (33 of 52) than in heifers ( 1 of 75). The values for size and growth rate of the ovulatory follicle were very different between single- and multiple-ovulating cows (Table 1), and it was unclear whether only the values for the largest follicle should be included or whether a mean value should be reported. Therefore, only data from single-ovulating cows were used for comparisons of follicular sizes and follicular growth rate to those in heifers. Data from all cows were utilized for comparison of the other measurements because comparison to only the subset $(36.5 \%)$ of cows that had single ovulation did not seem appropriate (Table 2). Although heifers had larger preovulatory follicles at the time of $\mathrm{PGF}_{2 \alpha}$ injection than cows with single ovulation, there was no 
Table 2. Multiple ovulation rate, follicular and luteal sizes, serum steroid concentrations at the time (d 7; ovulation $=\mathrm{d} 1$ ) and/or after $\mathrm{PGF}_{2 \alpha}$ injection, growth rate of the ovulatory follicle and days from $\mathrm{PGF}_{2 \alpha}$ injection to ovulation in heifers $(\mathrm{n}=28)$ and lactating cows $(\mathrm{n}=27)$ (experiment 1). ${ }^{1}$

\begin{tabular}{|c|c|c|c|}
\hline & Heifers & Lactating cows & $P$-value \\
\hline Multiple ovulation rate; \% (no./no.) & $1.3(1 / 75)$ & $63.5(33 / 52)$ & $<0.0001$ \\
\hline \multicolumn{4}{|l|}{ Data from single-ovulating animals } \\
\hline Size of ovulatory follicle at $\mathrm{PGF}_{2 \alpha}(\mathrm{mm})$ & $13.3 \pm 0.2(\mathrm{n}=74)$ & $12.2 \pm 0.4(\mathrm{n}=19)$ & 0.0307 \\
\hline Maximal size of ovulatory follicle (mm) & $16.5 \pm 0.2(\mathrm{n}=74)$ & $15.8 \pm 0.4(\mathrm{n}=19)$ & 0.1579 \\
\hline $\begin{array}{l}\text { Growth rate of ovulatory follicle after } \\
\text { PGF }_{2 \alpha}(\mathrm{mm} / \mathrm{d})\end{array}$ & $1.1 \pm 0.0(\mathrm{n}=74)$ & $1.0 \pm 0.1(\mathrm{n}=19)$ & 0.2905 \\
\hline \multicolumn{4}{|l|}{ Data from all animals } \\
\hline Estradiol peak near estr & $12.1 \pm 0.5(\mathrm{n}=56)$ & $8.6 \pm 0.6(n=43)$ & 0.0074 \\
\hline tion & $3.8 \pm 0.1(\mathrm{n}=75)$ & $4.6 \pm 0.1(\mathrm{n}=52)$ & $<0.0001$ \\
\hline Progesterone on d $7(\mathrm{ng} / \mathrm{ml})$ & $3.0 \pm 0.1(\mathrm{n}=79)$ & $2.0 \pm 0.1(\mathrm{n}=67)$ & $<0.0001$ \\
\hline Luteal tissue volume on $\mathrm{d} 7\left(\mathrm{~mm}^{3}\right)$ & $5515.2 \pm 273.4(\mathrm{n}=79)$ & $7293.6 \pm 304.8(\mathrm{n}=67)$ & 0.0003 \\
\hline
\end{tabular}

${ }^{1}$ All results are expressed as mean \pm SEM, except for multiple ovulation rate.

difference between groups for the maximal size of the ovulatory follicle (Table 2). Nevertheless, lactating cows had lower peak serum concentrations of $\mathrm{E}_{2}$ near estrus (Table 2). There was no difference between groups in the growth rate of the ovulatory follicle after luteolysis; however, lactating cows took almost $1 \mathrm{~d}$ longer to ovulate after CL regression (Table 2 and Figure 1). On $d$ 7 , lactating cows had greater $(P<0.01)$ luteal tissue volume, but heifers had greater $(P<0.01)$ serum $\mathrm{P}_{4}$ concentrations (Table 2).

Figure 1 shows the distribution for time from $\mathrm{PGF}_{2 \alpha}$ treatment until ovulation for lactating cows $(\mathrm{n}=67$ treatments) and heifers ( $\mathrm{n}=79$ treatments). Most of the heifers $(92.4 \%)$ ovulated on $\mathrm{d} 3$ and 4 after $\mathrm{PGF}_{2 \alpha}$ treatment, whereas most of the cows $(65.7 \%)$ ovulated on $\mathrm{d} 4$ and 5 . Four heifers (5.1\%) and 15 cows $(22.4 \%)$ did not ovulate after $\mathrm{PGF}_{2 \alpha}$ (Figure 1). Of these anovulatory

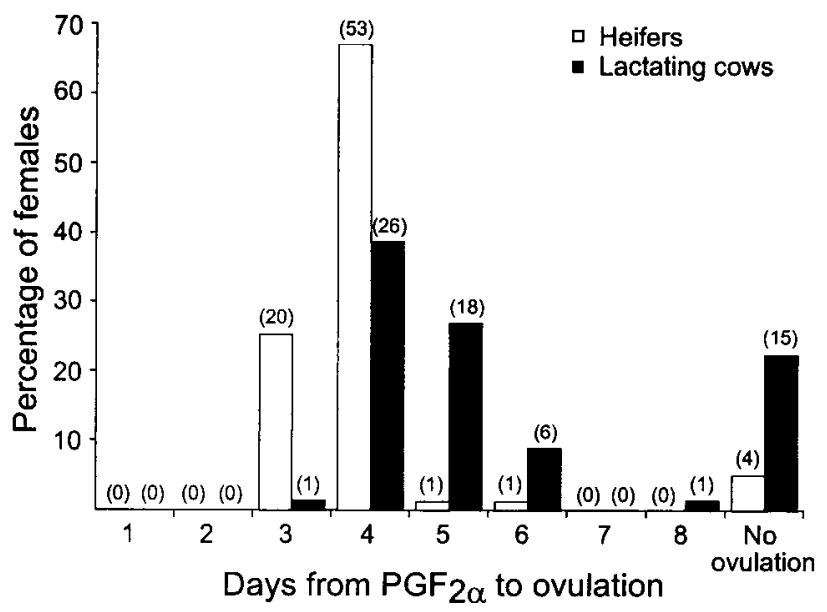

Figure 1. Percentage distribution by days from the time of $\mathrm{PGF}_{2 \alpha}$ treatment until ovulation for nulliparous heifers $(n=79$ treatments $)$ and lactating cows ( $\mathrm{n}=67$ treatments). Data within parentheses represent number of observations for each group at each day. cows, two heifers and two lactating cows did not demonstrate complete luteolysis as determined by ultrasound evaluation of the $\mathrm{CL}$ and serum $\mathrm{P}_{4}$ concentrations. The reason(s) for anovulation in the other cows was not clear.

\section{Experiment 2}

In contrast with experiment 1 , lactating cows had a lower incidence of multiple ovulation during winter (17.9\%), which was similar to the multiple ovulation rate for dry cows (17.2\%) (Table 3). Lactating cows tended to have a greater $(P=0.1)$ size of the ovulatory follicle at time of $\mathrm{PGF}_{2 \alpha}$ treatment and greater $(P<$ 0.06 ) growth rate of the future ovulatory follicle than dry cows (Table 3 ). In addition, lactating cows required a longer $(P<0.01)$ time from $\mathrm{PGF}_{2 \alpha}$ treatment until ovulation, and this resulted in ovulation of a larger $(P$ $<0.01$ ) follicle in lactating than dry cows (Table 3). In spite of the larger ovulatory follicle size, there was no difference in maximal serum $\mathrm{E}_{2}$ concentrations near the time of estrus between the groups. On d 7, lactating cows had greater $(P<0.01)$ luteal tissue volume than dry cows, but serum $\mathrm{P}_{4}$ concentrations were similar in the two groups (Table 3).

Figure 2 shows the distribution for time from $\mathrm{PGF}_{2 \alpha}$ treatment until ovulation for lactating $(\mathrm{n}=66$ treatments) and dry ( $\mathrm{n}=81$ treatments) cows. Most of the dry cows $(61.7 \%)$ had ovulated by d 4 after $\mathrm{PGF}_{2 \alpha}$ treatment in contrast with only $39.4 \%$ of lactating cows ( $P$ $<0.05$; Figure 2). A number of cows in both groups (17 dry and 10 lactating cows) did not ovulate after $\mathrm{PGF}_{2 \alpha}$ treatment (Figure 2). Of these anovulatory cows, five of the dry cows and five of the lactating cows did not demonstrate complete luteolysis as determined by ultrasound evaluation of the CL and serum $\mathrm{P}_{4}$ concentrations. The reasons for anovulation in the other cows were not clear. 
Table 3. Multiple ovulation rate, follicular and luteal sizes, serum steroid concentrations at the time $(\mathrm{d} 7$; ovulation $=\mathrm{d} 1)$ and/or after $\mathrm{PGF}_{2 \alpha}$ injection, growth rate of the ovulatory follicle and days from $\mathrm{PGF}_{2 \alpha}$ injection to ovulation in dry $(\mathrm{n}=26)$ and lactating cows $(\mathrm{n}=27)$ (experiment 2).

\begin{tabular}{|c|c|c|c|}
\hline & Dry cows & Lactating cows & $P$-value \\
\hline \multicolumn{4}{|l|}{ Data from single-ovulating animals } \\
\hline Size of ovulatory follicle at $\mathrm{PGF}_{2 \alpha}(\mathrm{mm})$ & $12.9 \pm 0.5(\mathrm{n}=53)$ & $14.0 \pm 0.5(\mathrm{n}=46)$ & 0.1000 \\
\hline \multicolumn{4}{|l|}{ Growth rate of ovulatory follicle after } \\
\hline $\mathrm{PGF}_{2 \alpha}(\mathrm{mm} / \mathrm{d})$ & $1.0 \pm 0.1(\mathrm{n}=53)$ & $1.2 \pm 0.1(\mathrm{n}=46)$ & 0.0580 \\
\hline \multicolumn{4}{|l|}{ Data from all animals } \\
\hline Progesterone on d $7(\mathrm{ng} / \mathrm{ml})$ & $1.9 \pm 0.1(\mathrm{n}=40)$ & $2.2 \pm 0.2(\mathrm{n}=36)$ & 0.1900 \\
\hline Luteal tissue volume on d $7\left(\mathrm{~mm}^{3}\right)$ & $5138.9 \pm 459.8(\mathrm{n}=40)$ & $7598.9 \pm 475.3(\mathrm{n}=36)$ & 0.0005 \\
\hline
\end{tabular}

${ }^{1}$ All results are expressed as mean \pm SEM, except for multiple ovulation rate.

Table 4 summarizes the results from the correlation analyses between size of ovulatory follicle (for single ovulating cows), CL volume, and serum $\mathrm{P}_{4}$ concentrations on $\mathrm{d} 7$ in heifers (experiment 1), lactating cows (experiments 1 and 2 combined), and dry cows (experiment 2$)$. There was a positive $(P<0.05)$ relationship between: 1) size of ovulatory follicle and CL volume; 2) size of ovulatory follicle and serum $\mathrm{P}_{4}$ concentration; and 3) CL volume and serum $\mathrm{P}_{4}$ concentration in both lactating cows and heifers. For dry cows, a significant $(P<0.05)$ positive correlation was only detected between size of the ovulatory follicle and CL volume (Table 4). Using data from single-ovulating females from all three groups, we found positive correlation coefficients between follicle size and CL volume $(\mathrm{r}=0.51 ; P$ $<0.0001)$, follicle size and serum $\mathrm{P}_{4}(\mathrm{r}=0.24 ; P=0.002)$, and CL volume and serum $\mathrm{P}_{4}(\mathrm{r}=0.31 ; P<0.0001)$.

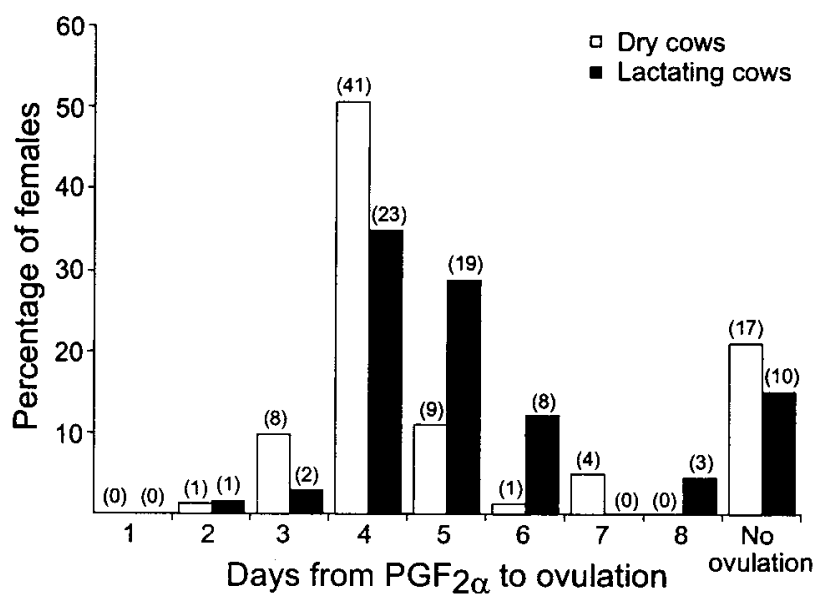

Figure 2. Percentage distribution by days from the time of $\mathrm{PGF}_{2 \alpha}$ treatment until ovulation for dry cows ( $\mathrm{n}=81$ treatments) and lactating cows $(\mathrm{n}=66$ treatments). Data within parentheses represent number of observations for each group at each day.
Figure 3 shows scatter plots of volume of the ovulatory follicle and CL volume (Figure 3A), and of serum $\mathrm{P}_{4}$ concentration and CL volume (Figure 3B). Regression lines shown in Figure 3 were estimated by using the regression-through-the-origin technique (Neter et al. 1996), i.e., forcing the regression to go through the origin at $(0,0)$. When the intercept was not forced to be zero, the estimated linear regressions were:

Lactating cows:

Follicle $=14.031+0.00048 \mathrm{CL}\left(\mathrm{R}^{2}=0.44, P<\right.$ $0.0001)$

$\mathrm{P}_{4}=1.177+0.00011 \mathrm{CL}\left(\mathrm{R}^{2}=0.20, P<0.0010\right)$

Dry cows:

Follicle $=13.400+0.00053 \mathrm{CL}\left(\mathrm{R}^{2}=0.22, P=0.006\right)$ $\mathrm{P}_{4}=1.2784+0.000077 \mathrm{CL}\left(\mathrm{R}^{2}=0.08, P=0.11\right)$

Heifers:

Follicle $=13.683+0.00040 \mathrm{CL}\left(\mathrm{R}^{2}=0.20, P<\right.$ 0.0001 )

$$
\mathrm{P}_{4}=2.2454+0.00014 \mathrm{CL}\left(\mathrm{R}^{2}=0.08, P=0.01\right)
$$

\section{DISCUSSION}

These studies were designed to determine physiological differences in follicular and luteal sizes and circulating $\mathrm{P}_{4}$ and $\mathrm{E}_{2}$ between lactating cows and virgin heifers and between lactating and dry cows. They were done in conjunction with studies of embryonic quality in lactating and nonlactating females (Sartori et al., 2002) in order to provide potential physiological explanations for differences in embryonic quality that were observed in those studies. The high multiple ovulation rate $(63.5 \%)$ in lactating cows in experiment 1 was an unexpected and particularly puzzling aspect of this study. It is not possible to determine the exact cause of this increased ovulation rate; however, lactating cows in experiment 1 were treated with rbST every $12 \mathrm{~d}$ to match requirements for a simultaneous milk production trial in our herd. Previous studies have reported 
Table 4. Correlation (r) tests among size of ovulatory follicle (in single-ovulating cows), corpus luteum (CL) volume on $\mathrm{d} 7$, and serum progesterone $\left(\mathrm{P}_{4}\right)$ concentration on $\mathrm{d} 7 \mathrm{~d} 1$ = ovulation) in nulliparous heifers during summer, lactating cows during summer and winter, and dry cows during winter. Number of observations for each test is expressed within parentheses.

\begin{tabular}{|c|c|c|c|c|c|c|}
\hline & \multicolumn{2}{|c|}{ Heifers } & \multicolumn{2}{|c|}{ Lactating cows } & \multicolumn{2}{|c|}{ Dry cows } \\
\hline & $\mathrm{CL}$ & $\mathrm{P}_{4}$ & CL & $\mathrm{P}_{4}$ & CL & $\mathrm{P}_{4}$ \\
\hline Follicle & $\begin{array}{l}\mathrm{r}=0.44 \\
P<0.0001 \\
(\mathrm{n}=78)\end{array}$ & $\begin{array}{l}\mathrm{r}=0.32 \\
P=0.0044 \\
(\mathrm{n}=78)\end{array}$ & $\begin{array}{l}\mathrm{r}=0.67 \\
P<0.0001 \\
(\mathrm{n}=51)\end{array}$ & $\begin{array}{l}\mathrm{r}=0.33 \\
P=0.0196 \\
(\mathrm{n}=51)\end{array}$ & $\begin{array}{l}\mathrm{r}=0.47 \\
P=0.0063 \\
(\mathrm{n}=33)\end{array}$ & $\begin{array}{l}\mathrm{r}=0.10 \\
P=0.5698 \\
(\mathrm{n}=34)\end{array}$ \\
\hline CL & - & $\begin{array}{l}\mathrm{r}=0.29 \\
P=0.0114 \\
(\mathrm{n}=78)\end{array}$ & - & $\begin{array}{l}\mathrm{r}=0.45 \\
P=0.0010 \\
(\mathrm{n}=51)\end{array}$ & - & $\begin{array}{l}\mathrm{r}=0.28 \\
P=0.1148 \\
(\mathrm{n}=33)\end{array}$ \\
\hline
\end{tabular}

rbST treatment did not change (reviewed by Lucy, 2000), increased (Jimenez-Krassel et al., 1999), or decreased (Santos et al., 2000) incidence of double ovulation. Alternatively, heat stress decreased follicular growth (Wilson et al., 1998a, 1998b) and may have been responsible for the decreased size of the future ovulatory follicle at the time of $\mathrm{PGF}_{2 \alpha}$ treatment. Cows with multiple ovulations were treated with $\mathrm{PGF}_{2 \alpha}$ just after follicular diameter deviation (Ginther et al., 1996), and the subsequent reduction in circulating $\mathrm{P}_{4}$ could have altered the follicular deviation mechanisms similar to what was observed after LH treatment (Sartori et al., 2001). The high double ovulation rate allowed some interesting comparisons of single- and multiple-ovulating lactating dairy cows although it may have con- founded some of the comparisons of heifers and lactating cows. In addition, the differing location, diets, and parity of animals may have confounded results in experiment 1. Regardless, the physiological conditions that produced this high ovulation rate appeared to be specific for experiment 1 because a much lower frequency of multiple ovulations (17.9\%) was found in experiment 2.

Results from experiment 1 showed greater peak $\mathrm{E}_{2}$ concentrations in heifers compared with lactating cows; however, no difference in size of the ovulatory follicle was detected. In our study, evaluating normal estrous cycles (Sartori et al., 2000), we found that heifers had both a greater peak $\mathrm{E}_{2}$ concentration $(9.4 \mathrm{vs} .7 .1 \mathrm{pg} / \mathrm{ml})$ and a significantly smaller ovulatory follicle size (14.8 vs. $17.4 \mathrm{~mm}$ ) compared with lactating cows. A recent

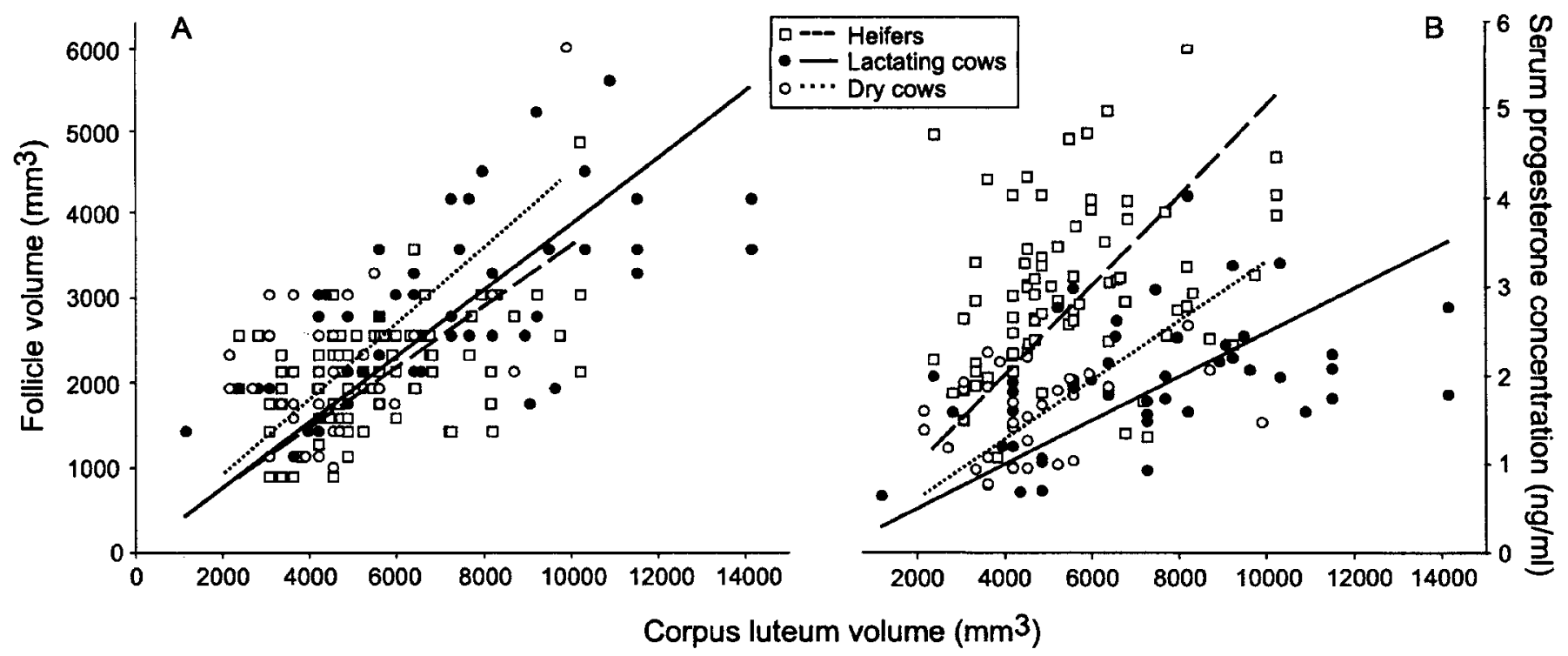

Figure 3. Scatter plot showing the relationship between: A) volume of the ovulatory follicle (Fol) and corpus luteum (CL) volume on d 7 of the estrous cycle; and B) serum progesterone $\left(\mathrm{P}_{4}\right)$ concentration and CL volume on $\mathrm{d} 7$ for single-ovulating females (heifers, $\mathrm{n}=78$ observations; lactating cows, $\mathrm{n}=51$ observations; dry cows, $\mathrm{n}=33$ observations). Estimated regression-through-the-origin models: Fol = $0.3833 \mathrm{CL}$ and $\mathrm{P}_{4}=0.00025 \mathrm{CL}$ for lactating cows (solid lines); Fol $=0.4506 \mathrm{CL}$ and $\mathrm{P}_{4}=0.00032 \mathrm{CL}$ for dry cows (dotted lines); and Fol $=$ $0.380 \mathrm{CL}$ and $\mathrm{P}_{4}=0.00050 \mathrm{CL}$ for heifers (dashed lines). 
study by Inbar et al. (2001) and the Cooperative Regional Project NE-161 (Ahmad et al., 1996) also reported similar differences between heifers and lactating cows. Moreover, studies comparing lactating with dry cows observed that lactating cows developed larger dominant follicles (De La Sota et al., 1993; Beam, 1995) but had lower (De La Sota et al., 1993) or similar (Beam, 1995) circulating concentrations of $\mathrm{E}_{2}$. In the present study, the average size of the ovulatory follicle of lactating cows was especially large in experiment 2 (18.6 $\mathrm{mm}$ ), but this was similar to the average diameter of ovulatory follicles in our study of lactating cows during the normal estrous cycle (17.4 mm; Sartori et al., 2000).

The greater size of the ovulatory follicle in lactating cows appears to be primarily related to an increased time for follicular growth as demonstrated by the greater time from $\mathrm{PGF}_{2 \alpha}$ to ovulation observed for lactating cows in both experiments 1 and 2 . The time from $\mathrm{PGF}_{2 \alpha}$ to estrus or ovulation is influenced by day of the estrous cycle and follicle developmental stage in the follicular wave at the time of $\mathrm{PGF}_{2 \alpha}$ injection (Momont and Seguin, 1984; Pursley and Wiltbank, unpublished results; Stevenson et al., 1998). In our experiments, follicular development at $\mathrm{PGF}_{2 \alpha}$ was expected to be similar for all groups because $\mathrm{PGF}_{2 \alpha}$ was given at a known stage of the first follicular wave ( $6 \mathrm{~d}$ after ovulation). In experiment 2 there was a tendency for a greater follicular size at time of $\mathrm{PGF}_{2 \alpha}$ in lactating cows; however, lactating cows still required a greater time from $\mathrm{PGF}_{2 \alpha}$ to ovulation. Because peak $\mathrm{E}_{2}$ concentrations were similar in lactating and dry cows (experiment 2), it seems clear that lactating cows require a larger follicular size and greater $\mathrm{E}_{2}$ production to achieve the circulating $\mathrm{E}_{2}$ concentrations necessary to produce an $\mathrm{LH}$ surge and ovulation. We have previously reported a very high rate of $\mathrm{E}_{2}$ metabolism in lactating cows related to elevated DMI (Sangsritavong et al., 2002). The higher peak $\mathrm{E}_{2}$ concentration in heifers as compared with lactating cows (experiment 1; Ahmad et al., 1996; Sartori et al., 2000; Inbar et al., 2001) is also consistent with high $\mathrm{E}_{2}$ metabolism in lactating cows.

The potential physiological consequences of reduced peak $\mathrm{E}_{2}$ and increased size of the ovulatory follicle are numerous. A reduction in peak circulating $\mathrm{E}_{2}$ could be a cause of any reduced length or intensity of behavioral estrus in lactating cows (Nebel et al., 1997) or a low estrous detection rate observed in lactating cows (Senger, 1994). However, our studies as well as other studies comparing behavioral estrus in heifers and lactating cows have any parity effects confounded with type of housing (usually dirt for heifers vs. concrete for lactating cows) and location. Lower concentrations of $\mathrm{E}_{2}$ before ovulation may also contribute to poor fertilization and poor early embryonic development (King et al.,
1994; DeSouza and Murray, 1995). In addition, reduced peak $\mathrm{E}_{2}$ may also alter aspects of the LH surge that could account for some types of anovulation in lactating cows (Wiltbank et al., 2002). The increased size of the ovulatory follicle and a delayed time to ovulation after luteolysis in lactating dairy cows may also have important effects on fertility. Vasconcelos et al. (1999) observed that cows ovulating larger follicles had lower conception rate $(\mathbf{C R})$ and a tendency for higher pregnancy loss than cows ovulating smaller follicles. Moreover, studies that induced persistent follicles in cattle (Sanchez et al., 1993; Savio et al., 1993; Wehrman et al., 1993; Ahmad et al., 1996; Kinder et al., 1996) observed lower fertility after ovulation of these persistent follicles compared with ovulation of smaller growing follicles. One study (Ahmad et al., 1996), for example, demonstrated that production of a persistent follicle decreased CR from 54 to $15 \%$ in lactating dairy cows.

There were also important differences in the CL between lactating and nonlactating females. Lactating cows had greater luteal tissue volume; however, they had either lower (experiment 1) or similar (experiment 2) circulating $\mathrm{P}_{4}$ concentrations than heifers and dry cows, respectively. Greater luteal volume is likely related to greater size of the ovulatory follicle. Vasconcelos et al. (2001) reported a reduced luteal volume in cows that were induced to ovulate smaller follicles. In the present study, there was a significant positive correlation between size of the ovulatory follicle and size of the CL in all groups. The regression line explaining this relationship did not differ between the three groups of animals, suggesting that this relationship may be relatively constant for various physiological states. It seems likely that increased follicular size would lead to increased numbers of granulosa cells. Following the LH surge, granulosa cells differentiate into large luteal cells (Smith et al., 1994). Large luteal cells account for less than $4 \%$ of the luteal cell number but $\sim 40 \%$ of the luteal volume (O'Shea et al., 1989). According to Niswender et al. (1985), the majority $(\sim 80 \%)$ of $\mathrm{P}_{4}$ secreted by the mature ovine CL is derived from large luteal cells. Thus, an increased number of granulosa cells would likely result in an increased number of large luteal cells and subsequent increased size of the CL and increased $\mathrm{P}_{4}$ secretion. Indeed, Milvae et al. (1991) reduced the number of granulosa cells in the ovulatory follicle of heifers and found a corresponding reduction in plasma $\mathrm{P}_{4}$ concentrations. Murdoch and Kirk (1998) observed lower serum $\mathrm{P}_{4}$ concentrations, lower luteal $\mathrm{P}_{4}$, and lower percentage of large luteal cells from ewes in which follicles were induced to ovulate earlier as compared with follicles that ovulated $24 \mathrm{~h}$ later. In that study, follicles induced to ovulate earlier had fewer granulosa cells but similar num- 
bers of theca interna cells. Studies comparing heifers and lactating cows throughout a normal estrous cycle (Sartori et al., 2000; Inbar et al., 2001) and between dry and lactating cows after synchronization of estrus with norgestomet implant and $\mathrm{PGF}_{2 \alpha}$ (De La Sota et al., 1993) have reported lower circulating $\mathrm{P}_{4}$ concentrations in lactating compared with nonlactating females. Thus, clearly, lactating cows ovulate larger follicles producing larger CL; however, circulating $\mathrm{P}_{4}$ concentrations are reduced despite greater luteal volume, possibly due to an increased rate of $\mathrm{P}_{4}$ metabolism in lactating cows. Similar to $\mathrm{E}_{2}$ infusion, we also found that continuous infusion of $\mathrm{P}_{4}$ at a constant rate produces much greater circulating $\mathrm{P}_{4}$ concentrations in dry cows than lactating cows of similar size (Sangsritavong et al., 2002). It seems likely that high feed consumption in lactating cows may be responsible for the increased steroid metabolism (Wiltbank et al., 2000). One other observation that was consistent with differences in $\mathrm{P}_{4}$ metabolism under different physiological conditions was the finding that the correlation between $\mathrm{P}_{4}$ concentration and CL volume was explained by a different regression line in heifers than in cows.

Reduced peri- and postovulatory circulating $\mathrm{P}_{4}$ concentrations could be responsible for some of the reduction in fertility in lactating dairy cows. Lower serum $\mathrm{P}_{4}$ concentrations before $\mathrm{AI}$ were associated with reduced fertility (Folman et al., 1973; Fonseca et al., 1983) and supplementation of $\mathrm{P}_{4}$ before AI increased PR (Folman et al., 1990; Wehrman et al., 1993; Xu et al., 1997). Low serum $\mathrm{P}_{4}$ concentration allows increased pulse frequency of LH (Roberson et al., 1989; Bergfelt et al., 1991; Adams et al., 1992), causing premature maturation of the oocyte (Revah and Butler, 1996) with a resulting decrease in oocyte quality at the time of ovulation, and consequently, low embryo quality after fertilization (Ahmad et al., 1995). Reduced $\mathrm{P}_{4}$ concentrations after $\mathrm{AI}$ also are associated with reduced fertility (Henricks et al., 1971; Lukaszewska and Hansen, 1980; Mann et al., 1995; Ahmad et al., 1996; Larson et al., 1997). Vasconcelos et al. (2001) showed that ovulation of very small follicles in lactating cows $(11.5 \pm 0.2 \mathrm{~mm})$ resulted in smaller CL, lower serum $\mathrm{P}_{4}$ concentrations, and lower CR compared with ovulation of larger follicles $(14.5 \pm 0.2 \mathrm{~mm})$. This reduction in CR may be due to lower circulating $\mathrm{P}_{4}$ concentration that may hamper embryo development (Mann et al., 1998), and/or allow earlier induction of luteolytic mechanisms (Mann and Lamming, 1995; Mann et al., 1995). Lynch et al. (1999) improved $\mathrm{CR}$ in cows using intravaginal $\mathrm{P}_{4}$ releasing devices for $10 \mathrm{~d}$ starting on $\mathrm{d} 2$ or 3 after estrus, combined with a GnRH injection on d 12 or 13. Studies in sheep and cattle also showed that $\mathrm{P}_{4}$ administration during the first 4 to $6 \mathrm{~d}$ after insemination resulted in increased embryonic or fetal growth (Garrett et al., 1988; Kleemann et al., 1994). Moreover, interferon $\tau$ production on d 16 is closely related to the circulating $\mathrm{P}_{4}$ pattern (Kerbler et al., 1997; Mann et al., 1998). Thus, decreased embryonic development in lactating dairy cows (Sartori et al., 2002) could be due to multiple differences that were found between lactating cows vs. heifers or dry cows including increased size of the ovulatory follicle and/or decreased serum $\mathrm{P}_{4}$ concentrations either before or after AI. Manipulative studies will be required to determine the importance of each of these reproductive changes in reducing embryonic development in lactating dairy cows.

\section{CONCLUSIONS}

In general, the results from the experiments supported our original hypotheses that lactating cows would ovulate larger follicles but have similar circulating $\mathrm{E}_{2}$, and would have larger CL but similar circulating $\mathrm{P}_{4}$ compared with heifers or dry cows. These discrepancies are expected to be due to greater steroid metabolism in lactating cows. Lower serum steroid concentrations have numerous potential physiological consequences that may compromise fertility in lactating cows.

\section{ACKNOWLEDGMENTS}

The authors thank Jerry N. Guenther and Siegrid A. Mertens for their technical assistance at the Dairy Cattle Center and Josie Lewandowski for her help with the steroid assays. We also thank Merial Ltd. for providing GnRH (Cystorelin). This research was supported by Wisconsin State experiment Station, USDA grant 2000-2276, and the fellowship BEX 1811/97-5 from CAPES of Brazil to Roberto Sartori.

\section{REFERENCES}

Adams, G. P., R. L. Matteri, J. P. Kastelic, J. C. H. Ko, and O. J. Ginther. 1992. Association between surges of follicle-stimulating hormone and the emergence of follicular waves in heifers. J. Reprod. Fertil. 94:177-188.

Ahmad, N., S. W. Beam, W. R. Butler, D. R. Deaver, R. T. Duby, D. R. Elder, J. E. Fortune, L. C. Griel, L. S. Jones, R. A. Milvae, J. L. Pate, I. Revah, D. T. Schreiber, D. H. Townson, P. C. W. Tsang, and E. K. Inskeep. 1996. Relationship of fertility to patterns of ovarian follicular development and associated hormonal profiles in dairy cows and heifers. J. Anim. Sci. 74:1943-1952.

Ahmad, N., F. N. Schrick, R. L. Butcher, and E. K. Inskeep. 1995. Effect of persistent follicles on early embryonic losses in beef cows. Biol. Reprod. 52:1129-1135.

Beam, S. W. 1995. Follicular development in postpartum dairy cattle: effects of energy balance and dietary lipid. Ph.D. Diss., Cornell University, Cornell.

Bergfelt, D. R., J. P. Kastelic, and O. J. Ginther. 1991. Continued periodic emergence of follicular waves in non-bred progesteronetreated heifers. Anim. Reprod. Sci. 24:193-204. 
Butler, W. R. 1998. Review: Effect of protein nutrition on ovarian and uterine physiology in dairy cattle. J. Dairy Sci. 81:2533-2539.

De La Sota, R. L., M. C. Lucy, C. R. Staples, and W. W. Thatcher. 1993. Effects of recombinant bovine somatotropin (Sometribove) on ovarian function in lactating and nonlactating dairy cows. J. Dairy Sci. 76:1002-1013.

DeSouza, M. M., and M. K. Murray. 1995. An estrogen-dependent secretory protein, which shares identity with chitinases, is expressed in a temporally and regionally specific manner in the sheep oviduct at the time of fertilization and embryo development. Endocrinology 136:2485-2496.

Faust, M. A., B. T. McDaniel, O. W. Robison, and J. H. Britt. 1988. Environmental and yield effects on reproduction in primiparous Holsteins. J. Dairy Sci. 71:3092-3099.

Folman, Y., M. Kaim, Z. Herz, and M. Rosenberg. 1990. Comparison of methods for the synchronization of estrous cycles in dairy cows. 2. Effects of progesterone and parity on conception. J. Dairy Sci. 73:2817-2825.

Folman, Y., M. Rosenberg, Z. Herz, and M. Davidson. 1973. The relationship between plasma progesterone concentration and conception in post-partum dairy cows maintained on two levels of nutrition. J. Reprod. Fertil. 34:267-278.

Fonseca, F. A., J. H. Britt, B. T. McDaniel, J. C. Wilk, and A. H. Rakes. 1983. Reproductive traits of Holstein and Jerseys. Effects of age, milk yield, and clinical abnormalities on involution of cervix and uterus, ovulation, estrous cycles, detection of estrus, conception rate, and days open. J. Dairy Sci. 66:1128-1147.

Garrett, J. E., R. D. Geisert, M. T. Zavy, and G. L. Morgan. 1988. Evidence for maternal regulation of early conceptus growth and development in beef cattle. J. Reprod. Fertil. 84:437-446.

Ginther, O. J., M. C. Wiltbank, P. M. Fricke, J. R. Gibbons, and K. Kot. 1996. Selection of the dominant follicle in cattle. Biol. Reprod. $55: 1187-1194$

Harrison, R. O., S. P. Ford, J. W. Young, A. J. Conley, and A. E. Freeman. 1990. Increased milk production vs. reproductive and energy status of high producing dairy cows. J. Dairy Sci. 73:2749-2758.

Henricks, D. M., D. R. Lamond, J. R. Hill, and J. F. Dickey. 1971. Plasma progesterone concentrations before mating and in early pregnancy in the beef heifer. J. Anim. Sci. 33:450-454.

Inbar, G., D. Wolfenson, Z. Roth, M. Kaim, A. Block, and R. BrawTal. 2001. Follicular dynamics and concentrations of steroids and gonadotropins in lactating cows and nulliparous heifers. J. Dairy Sci. 84(Suppl. 1):465(Abstr.).

Jimenez-Krassel, F., M. Binelli, H. A. Tucker, and J. J. Ireland. 1999. Effect of long-term infusion with recombinant growth hormonereleasing factor and recombinant bovine somatotropin on development and function of dominant follicles and corpora lutea in Holstein cows. J. Dairy Sci. 82:1917-1926.

Kerbler, T. L., M. M. Buhr, L. T. Jordan, K. E. Leslie, and J. S. Walton. 1997. Relationship between maternal plasma progesterone concentration and interferon-tau synthesis by the conceptus in cattle. Theriogenology 47:703-714.

Kinder, J. E., F. N. Kojima, E. G. M. Bergfeld, M. E. Wehrman, and K. E. Fike. 1996. Progestin and estrogen regulation of pulsatile $\mathrm{LH}$ release and development of persistent ovarian follicles in cattle. J. Anim. Sci. 74:1424-1440.

King, R. S., S. H. Anderson, and G. J. Killian. 1994. Effect of bovine oviductal estrus-associated protein on the ability of sperm to capacitate and fertilize oocytes. J. Androl. 15:468-478.

Kleemann, D. O., S. K. Walker, and R. F. Seamark. 1994. Enhanced fetal growth in sheep administered progesterone during the first three days of pregnancy. J. Reprod. Fertil. 102:411-417.

Kulick, L. J., K. Kot, M. C. Wiltbank, and O. J. Ginther. 1999. Follicular and hormonal dynamics during the first follicular waves in heifers. Theriogenology 52:913-921.

Larson, S. F., W. R. Butler, and W. B. Currie. 1997. Reduced fertility associated with low progesterone postbreeding and increased milk urea nitrogen in lactating cows. J. Dairy Sci. 80:1288-1295.

Littell, R. C., G. A. Miliken, W. W. Stroup, and R. D. Wolfinger. 1996. SAS System for Mixed Models. 633 pp. SAS Institute Inc., Cary, NC.
Lucy, M. C. 2000. Regulation of ovarian follicular growth by somatotropin and insulin-like growth factors in cattle. J. Dairy Sci. 83:1635-1647.

Lukaszewska, J., and W. Hansel. 1980. Corpus luteum maintenance during early pregnancy in the cow. J. Reprod. Fert. 59:485-493.

Lynch, P. R., K. L. Macmillan, and V. K. Taufa. 1999. Treating cattle with progesterone as well as a GnRH analogue affects oestrous cycle length and fertility. Anim. Reprod. Sci. 56:189-200.

Mann, G. E., and G. E. Lamming. 1995. Progesterone inhibition of the development of the luteolytic signal in cows. J. Reprod. Fertil. 104:1-5.

Mann, G. E., G. E. Lamming, and M. D. Fray. 1995. Plasma oestradiol and progesterone during early pregnancy in the cow and the effects of treatment with buserelin. Anim. Reprod. Sci. 37:121131.

Mann, G. E., G. E. Lamming, R. S. Robinson, and D. C. Wathes. 1998. The regulation of interferon- $\tau$ production and uterine hormone receptors during early pregnancy. J. Reprod. Fertil. 54(Suppl.):317-328.

Milvae, R. A., H. W. Alila, S. L. Bushmich, and W. Hansel. 1991. Bovine corpus-luteum function after removal of granulosa-cells from the preovulatory follicle. Domestic Animal Endocrinology. 8:439-443

Momont, H. W., and B. E. Seguin. 1984. Influence of day of estrous cycle on response to $\mathrm{PGF}_{2 \alpha}$ products: implications for $\mathrm{AI}$ programs for dairy cattle. Pages 336.1-336-3 in 10th Proc. Internatl. Congr. Anim. Reprod. and AI, Urbana-Champaign, IL. Univ. of Illinois, Urbana-Champaign, IL

Murdoch, W. J., and E. A. V. Kirk. 1998. Luteal dysfunction in ewes induced to ovulate early in the follicular phase. Endocrinology 139:3480-3484.

Nebel, R. L., S. M. Jobst, M. B. G. Dransfield, S. M. Pandolfi, and T. L. Bailey. 1997. Use of a radiofrequency data communication system, Heat Watch, to describe behavioral estrus in dairy cattle. J. Dairy Sci. 80(Suppl. 1):151(Abstr.).

Nebel, R. L., and M. L. McGilliard. 1993. Interactions of high milk yield and reproductive performance in dairy cows. J. Dairy Sci. 76:3257-3268.

Neter, J., M. H. Kutner, C. J. Nachtsheim, and W. Wasserman. 1996. Applied Linear Statistical Models. 1408 pp. Irwin, Chicago, IL.

Niswender, G. D., R. H. Schwall, T. A. Fitz, C. E. Farin, and H. R. Sawyer. 1985. Regulation of luteal function in domestic ruminants: new concepts. Recent Prog. Horm. Res. 41:101-105.

O'Shea, J. D., R. J. Rodgers, and M. J. D'Occhio. 1989. Cellular composition of the cyclic corpus luteum of the cow. J. Reprod. Fertil. 85:483.

Parr, R. A., I. F. Davis, M. A. Miles, and T. J. Squires. 1993a. Feedintake affects metabolic-clearance rate of progesterone in sheep. Res. Vet. Sci. 55:306-310.

Parr, R. A., I. F. Davis, M. A. Miles, and T. J. Squires. 1993b. Liver blood flow and metabolic clearance rate of progesterone in sheep. Res. Vet. Sci. 55:311-316.

Pursley, J. R., M. O. Mee, and M. C. Wiltbank. 1995. Synchronization of ovulation in dairy cows using $\mathrm{PGF}_{2 \alpha}$ and $\mathrm{GnRH}$. Theriogenology 44:915-923.

Rasmussen, F. E., M. C. Wiltbank, J. O. Christensen, and R. R. Grummer. 1996. Effects of fenprostalene and estradiol-17 $\beta$ benzoate on parturition and retained placenta in dairy cows and heifers. J. Dairy Sci. 79:227-234.

Revah, I., and W. R. Butler. 1996. Prolonged dominance of follicles and reduced viability of bovine oocytes. J. Reprod. Fertil. 106:39-47.

Roberson, M. S., M. W. Wolfe, T. T. Stumpf, R. J. Kittok, and J. E. Kinder. 1989. Luteinizing hormone secretion and corpus luteum function in cows receiving two levels of progesterone. Biol. Reprod. 41:997-1003.

Sanchez, T., M. E. Wehrman, E. G. Bergfeld, K. E. Peters, F. N. Kojima, A. S. Cupp, V. Mariscal, R. J. Kittok, R. J. Rasby, and J. E. Kinder. 1993. Pregnancy rate is greater when the corpus luteum is present during the period of progestin treatment to synchronize time of estrus in cows and heifers. Biol. Reprod. 49:1102-1107. 
Sangsritavong, S., D. K. Combs, R. Sartori, and M. C. Wiltbank. 2002. High feed intake increases blood flow and metabolism of progesterone and estradiol-17 $\beta$ in dairy cattle. J. Dairy Sci. 85:2831-2842.

Santos, J. E., J. T. Huber, C. B. Theurer, C. B. Nussio, L. G. Nussio, M. Tarazon, and D. Fish. 2000. Effects of grain processing and bovine somatotropin on metabolism and ovarian activity of dairy cows during early lactation. J. Dairy Sci. 83:1004-1015.

Sartori, R., P. M. Fricke, J. C. P. Ferreira, O. J. Ginther, and M. C. Wiltbank. 2001. Follicular deviation and acquisition of ovulatory capacity in bovine follicles. Biol. Reprod. 65:1403-1409.

Sartori, R., J. Haughian, G. J. M. Rosa, R. D. Shaver, and M. C. Wiltbank. 2000. Differences between lactating cows and nulliparous heifers in follicular dynamics, luteal growth, and serum steroid concentrations. J. Dairy Sci. 83(Suppl. 1):212(Abstr.)

Sartori, R., R. Sartor-Bergfelt, S. A. Mertens, J. N. Guenther, J. J. Parrish, and M. C. Wiltbank. 2002. Fertilization and early embryonic development in heifers and lactating cows in summer and lactating and dry cows in winter. J. Dairy Sci. 85:2803-2812.

SAS/STAT User's Guide, Release 6.12. 1996. SAS Institute, Inc., Cary NC.

Savio, J. D., W. W. Thatcher, L. Badinga, R. L. De La Sota, and D. Wolfenson. 1993. Regulation of dominant follicle turnover during the oestrous cycle in cows. J. Reprod Fertil. 97:197-203.

Senger, P. L. 1994. The estrus detection problem-new concepts, technologies, and possibilities. J. Dairy Sci. 77:2745-2753.

Sirois, J., and J. E. Fortune. 1990. Lengthening the bovine estrous cycle with low levels of exogenous progesterone: A model for studying ovarian follicular dominance. Endocrinology 127:916-925.

Smith, M. F., E. W. McIntush, and G. W. Smith. 1994. Mechanisms associated with corpus-luteum development. J. Anim. Sci. $72: 1857-1872$.

Stevenson, J. S., G. C. Lamb, Y. Kobayashi, and D. P. Hofman. 1998. Luteolysis during two stages of the estrous cycle: subsequent endocrine profiles associated with radiotelemetrically detected estrus in heifers. J. Dairy Sci. 81:2897-2903.

Vasconcelos, J. L. M., K. A. Bungert, S. J. Tsai, F. S. Wechsler, and M. C. Wiltbank. 1998. Acute reduction in serum progesterone concentrations due to feed intake in pregnant lactating dairy cows. J. Dairy Sci. 81(Suppl. 1):226(Abstr.).

Vasconcelos, J. L. M., R. Sartori, H. N. Oliveira, J. G. Guenther, and M. C. Wiltbank. 2001. Reduction in size of the ovulatory follicle reduces subsequent luteal size and pregnancy rate. Theriogenology 56:307-314.

Vasconcelos, J. L. M., R. W. Silcox, G. J. M. Rosa, J. R. Pursley, and M. C. Wiltbank. 1999. Synchronization rate, size of the ovulatory follicle, and conception rate after synchronization of ovulation beginning on different days of the estrous cycle in lactating dairy cows. Theriogenology 52:1067-1078.

Washburn, S. P., W. J. Silvia, C. H. Brown, B. T. McDaniel, and A. J. McAllister. 2002. Trends in reproductive performance in southeastern Holstein and Jersey DHI herds. J. Dairy Sci. 85:244-251.

Wehrman, M. E., M. S. Roberson, A. S. Cupp, F. N. Kojima, T. T. Stumpf, L. A. Werth, M. W. Wolfe, R. J. Kittok, and J. E. Kinder. 1993. Increasing exogenous progesterone during synchronization of estrus decreases endogenous $17 \beta$-estradiol and increases conception in cows. Biol. Reprod. 49:214-220.

Wilson, S. J., C. J. Kirby, A. T. Koenigsfeld, D. H. Keisler, and M. C. Lucy. 1998a. Effects of controlled heat stress on ovarian function of dairy cattle. 2. heifers. J. Dairy Sci. 81:2132-2138.

Wilson, S. J., R. S. Marion, J. N. Spain, D. E. Spiers, D. H. Keisler, and M. C. Lucy. 1998b. Effects of controlled heat stress on ovarian function of dairy cattle. 1. lactating cows. J. Dairy Sci. 81:2124-2131.

Wiltbank, M. C., P. M. Fricke, S. Sangsritavong, R. Sartori, and O. J. Ginther. 2000. Mechanisms that prevent and produce double ovulations in dairy cattle J. Dairy Sci. 83:2998-3007.

Wiltbank, M. C., A. Gümen, and R. Sartori. 2002. Physiological classification of anovulatory conditions in cattle. Theriogenology 57:21-52.

Xu, Z. Z., L. J. Burton, and K. L. MacMillan. 1997. Reproductive performance of lactating dairy cows following estrus synchronization regimens with $\mathrm{PGF}_{2 \alpha}$ and progesterone. Theriogenology $47: 687-701$ 